\title{
Determination of Quality outcome indicators in National Quality Assurance Standards (NQAS) accredited Hematology and Clinical Pathological laboratory
}

\author{
Killol Nathubhai Desai* and Chiragkumar B Menapara \\ Dept. of Pathology, GMERS Medical College, Junagadh, Gujarat, India
}

\begin{abstract}
Background: Laboratory plays a vital role in disease control and prevention by providing timely data or information for patient management and disease surveillance. Quality in laboratory has huge impact on diagnosis and patient management as about $80 \%$ of all diagnosis is made on the basis of laboratory tests.

Methods: The study was conducted in Central Diagnostic Laboratories of GMERS Medical College, Junagadh which is NQAS (National Quality Assurance Standards). The hospital uses internet and data is retrieved by the systems department. The study was conducted from January 2015 to December 2018. A total of 2,13,476 samples were received in the hematology and clinical pathology section. Different quality outcome indicators of hematology and clinical pathology laboratory were studied.

Result: All Quality parameters were consistently improved from 2015 to 2018 due to new instrumentation, IQC, EQC, timely instrument maintenance, laboratory information system (LIS), telephonic communications and monthly-yearly quality improvement meetings. Some important indicators like TAT, critical alert were not reach up to the target value but due continuous improvement plane we soon reach target level.

Conclusion: The concept of quality indicators has revolutionized the field of laboratory medicine. These indicators are of most importance in the comparison of individual laboratory performance with the aim of improving laboratory services and quality.
\end{abstract}

Keywords: National Quality Assurance Standards, Quality Outcome Indicator, Turn Around Time

\section{Introduction}

Laboratory plays a vital role in disease control and prevention by providing timely data or information for patient management and disease surveillance. ${ }^{[1]}$ Quality in laboratory has huge impact on diagnosis and patient management as about $80 \%$ of all diagnosis is made on the basis of laboratory tests. ${ }^{[2]}{ }^{[3]}$ The increasingly dominant role of laboratory medicine in clinical decision making and the pressure on cost containment have led to a more careful evaluation of the effectiveness of, and improvement in, clinical outcomes. Because laboratory tests play an extremely important role in diagnosing, monitoring, and evaluating patient outcomes, evidence-based evaluation of laboratory performances is crucial to ensuring that patients receive safe, efficient, and effective care. Measurement of the quality is critical to improvement of processes and outcomes. This area of concern has four standard measures for quality- Productivity, Efficiency, Clinical Care and Service quality in terms of measurable indicators. ${ }^{[4]}$

\section{Materials and Methods}

The study was conducted in Central Diagnostic Laboratories of GMERS Medical College, Junagadh which is NQAS
(National Quality Assurance Standards). The hospital uses internet and data is retrieved by the systems department. The study was conducted from January 2015 to December 2018. A total of 2,13,476 samples were received in the hematology and clinical pathology section. Different quality outcome indicators of hematology and clinical pathology laboratory were studied. ${ }^{[5]}$ (Table 1) Following instruments were used in our laboratory for sample processing: Horiba Pentra XLR 5 part fully automated hematology analyzer, Arkray AE 4020 urine analyzer and ARX-Clot semi-automated coagulation analyzer. For Internal Quality Control (IQC), three level commercial quality controls were used for hematology tests and two level quality controls were used for both coagulation tests and urine tests. For External Quality Control (EQA) in hematology we received samples from All India Institute of Medical Sciences, New Delhi under ISHTM - AIIMS EQAP PROGRAMME and for coagulation studies, we received samples from Christian Medical College, Vellore under ISHBT- CMC EQAS. Samples were received quarterly in a year.

\section{Result:}

Over a period of 4 years, a total of 2,13,476 samples were received in our hematology and clinical pathology 
laboratory. The below quality indicators were studied and documented every month. (Table-2)

\section{Discussion}

All Quality parameters were consistently improved from 2015 to 2018 due to new instrumentation, IQC, EQC, timely instrument maintenance, laboratory information system (LIS), telephonic communications and monthlyyearly quality improvement meetings. Some important indicators like TAT, critical alert were not reach up to the target value but due continuous improvement plane we soon reach target level. One of the most visible and talked about areas of laboratory service is how fast a test result is returned to a caregiver. ${ }^{[6]}$ Our study reveals TAT of $6.0 \%$ while Steindel SJ, Novis DA (1999) ${ }^{[6]}$ reported it to be $10.4 \%$. The potential for technological solutions to improve the process of critical value reporting is evident in numerous reports. ${ }^{[7,8]}$ The use of information technology

Table 1: Quality outcome indicators in Hematology and Clinical Pathological laboratory.

\begin{tabular}{|c|c|c|c|c|c|}
\hline Type & $\begin{array}{l}\text { Sr. } \\
\text { No }\end{array}$ & Quality Indicator & Frequency & source of data & Significance \\
\hline \multirow[t]{6}{*}{ Productivity } & 1 & $\begin{array}{l}\text { Number of Blood smear examined } \\
\text { done per } 1000 \text { population }\end{array}$ & Monthly & $\begin{array}{l}\text { Lab Register, systems } \\
\text { department }\end{array}$ & $\begin{array}{l}\text { Indicator to measure Utilization } \\
\text { of blood smear services of } \\
\text { Laboratory }\end{array}$ \\
\hline & 2 & $\begin{array}{l}\text { Number of HB test done per } 1000 \\
\text { population }\end{array}$ & Monthly & $\begin{array}{l}\text { Lab Register, systems } \\
\text { department }\end{array}$ & $\begin{array}{l}\text { Indicator to measure Utilization } \\
\text { of HB services of Laboratory }\end{array}$ \\
\hline & 3 & Lab test done per patient to OPD & Monthly & $\begin{array}{l}\text { Lab Register, systems } \\
\text { department }\end{array}$ & $\begin{array}{l}\text { Indicator to measure Utilization } \\
\text { of laboratory services by OPD } \\
\text { patients }\end{array}$ \\
\hline & 4 & Lab test done per patients IPD & Monthly & $\begin{array}{l}\text { Lab Register, systems } \\
\text { department }\end{array}$ & $\begin{array}{l}\text { Indicator to measure Utilization } \\
\text { of laboratory services by } \\
\text { indoor patients }\end{array}$ \\
\hline & 5 & Proportion of lab test done at night & Monthly & $\begin{array}{l}\text { Lab Register, systems } \\
\text { department }\end{array}$ & $\begin{array}{l}\text { Indicator to measure Utilization } \\
\text { of laboratory services during } \\
\text { night time }\end{array}$ \\
\hline & 6 & $\begin{array}{l}\text { Proportion of lab test done for } \\
\text { BPL patients }\end{array}$ & Monthly & $\begin{array}{l}\text { Lab Register, systems } \\
\text { department }\end{array}$ & $\begin{array}{l}\text { Indicator to measure Utilization } \\
\text { of laboratory services by BPL } \\
\text { patients }\end{array}$ \\
\hline \multirow[t]{5}{*}{ Efficiency } & 7 & $\begin{array}{l}\text { Number of test matched in } \\
\text { validation by EQAP-AlIMS, Delhi }\end{array}$ & Monthly & $\begin{array}{l}\text { EQAP Assessment } \\
\text { sheet }\end{array}$ & $\begin{array}{l}\text { Indicator to measure clinical } \\
\text { efficiency of laboratory }\end{array}$ \\
\hline & 8 & $\begin{array}{l}\text { Z Score for Haematology ( or } \\
\text { Equivalent) in EQAP-AlIMS, Delhi }\end{array}$ & Monthly & $\begin{array}{l}\text { EQAP Assessment } \\
\text { sheet }\end{array}$ & $\begin{array}{l}\text { Indicator to measure clinical } \\
\text { efficiency of Haematology lab }\end{array}$ \\
\hline & 9 & Down time critical equipment & Monthly & $\begin{array}{l}\text { Equipment } \\
\text { Maintenance Register }\end{array}$ & $\begin{array}{l}\text { Indicator for measuring } \\
\text { efficiency of critical equipment }\end{array}$ \\
\hline & 10 & $\begin{array}{l}\text { \% Investigations out of Turn } \\
\text { around time for routine lab } \\
\text { investigations }\end{array}$ & Monthly & $\begin{array}{l}\text { Lab Register, systems } \\
\text { department }\end{array}$ & $\begin{array}{l}\text { Timely reporting of laboratory } \\
\text { tests improve patient care } \\
\text { efficiency, effectiveness, and } \\
\text { satisfaction }\end{array}$ \\
\hline & 11 & $\begin{array}{l}\text { \% Investigations out of Turn } \\
\text { around time for emergency lab } \\
\text { investigations }\end{array}$ & Monthly & $\begin{array}{l}\text { Lab Register, systems } \\
\text { department }\end{array}$ & $\begin{array}{l}\text { Timely reporting of laboratory } \\
\text { tests improve patient care } \\
\text { efficiency, effectiveness, and } \\
\text { satisfaction }\end{array}$ \\
\hline \multirow[t]{2}{*}{$\begin{array}{l}\text { Clinical } \\
\text { care and } \\
\text { safety }\end{array}$} & 12 & $\begin{array}{l}\% \text { of Critical values reported } \\
\text { within one hour }\end{array}$ & Monthly & $\begin{array}{l}\text { Lab Register, systems } \\
\text { department }\end{array}$ & $\begin{array}{l}\text { Critical values reporting is } \\
\text { considered an important } \\
\text { laboratory process because } \\
\text { it can impact clinical decision } \\
\text { making, patient safety, and } \\
\text { operational efficiency. }\end{array}$ \\
\hline & 13 & $\begin{array}{l}\text { Number of adverse events per } \\
\text { thousand patients }\end{array}$ & Monthly & $\begin{array}{l}\text { Adverse event } \\
\text { reporting register }\end{array}$ & $\begin{array}{l}\text { Indicator for measuring } \\
\text { adverse events }\end{array}$ \\
\hline
\end{tabular}




\begin{tabular}{|l|l|l|l|l|l|}
\hline Type & $\begin{array}{l}\text { Sr. } \\
\text { No }\end{array}$ & Quality Indicator & Frequency & source of data & Significance \\
\hline $\begin{array}{l}\text { Clinical } \\
\text { care and } \\
\text { safety }\end{array}$ & 14 & Report correlation rate & Monthly & $\begin{array}{l}\text { Audit and feedback } \\
\text { record register }\end{array}$ & $\begin{array}{l}\text { Indicator to measure quality of } \\
\text { lab reporting }\end{array}$ \\
\cline { 2 - 6 } & 15 & $\begin{array}{l}\text { Proportion of false positive/false } \\
\text { negative for Malaria pf/pv antigen } \\
\text { test }\end{array}$ & Monthly & Lab Register & $\begin{array}{l}\text { Indicator to measure quality of } \\
\text { rapid diagnostic kit }\end{array}$ \\
\hline $\begin{array}{l}\text { Service } \\
\text { Quality } \\
\text { Indicator }\end{array}$ & 16 & $\begin{array}{l}\text { Waiting time at sample collection } \\
\text { area }\end{array}$ & Monthly & Time motion study & $\begin{array}{l}\text { Indicator for measuring service } \\
\text { Quality during routine working } \\
\text { time }\end{array}$ \\
\cline { 2 - 6 } & 17 & $\begin{array}{l}\text { Number of stock out incidences of } \\
\text { Reagents }\end{array}$ & Monthly & Stock Register & $\begin{array}{l}\text { Indicator for measure } \\
\text { availability of reagents }\end{array}$ \\
\hline
\end{tabular}

Table 2: Last three years performance and target values of Quality outcome indicators in Hematology and Clinical Pathological laboratory

\begin{tabular}{|c|c|c|c|c|c|c|c|}
\hline Type & $\begin{array}{l}\text { Sr. } \\
\text { No }\end{array}$ & Quality Indicator & $\begin{array}{l}\text { Year } \\
2015\end{array}$ & $\begin{array}{l}\text { Year } \\
2016\end{array}$ & $\begin{array}{l}\text { Year } \\
2017\end{array}$ & $\begin{array}{l}\text { Year } \\
2018\end{array}$ & Target \\
\hline \multirow[t]{6}{*}{ Productivity } & 1 & $\begin{array}{l}\text { Number of Blood smear examined done } \\
\text { per } 1000 \text { population }\end{array}$ & 0.5 & 1.1 & 1.9 & 2.5 & $>1$ \\
\hline & 2 & $\begin{array}{l}\text { Number of HB test done per } 1000 \\
\text { population }\end{array}$ & 0.9 & 1.5 & 2.4 & 3.2 & $>2$ \\
\hline & 3 & Lab test done per patient to OPD & 0.2 & 0.4 & 1.2 & 1.4 & $>0.5$ \\
\hline & 4 & Lab test done per patients IPD & 0.6 & 0.65 & 0.8 & 0.85 & $>0.5$ \\
\hline & 5 & Proportion of lab test done at night & 0.06 & 0.10 & 0.12 & 0.23 & $>0.2$ \\
\hline & 6 & $\begin{array}{l}\text { Proportion of lab test done for BPL } \\
\text { patients }\end{array}$ & 0.5 & 0.63 & 0.8 & 1.1 & ------ \\
\hline \multirow[t]{5}{*}{ Efficiency } & 7 & $\begin{array}{l}\text { Number of test matched in validation by } \\
\text { EQAP-AlIMS, Delhi }\end{array}$ & $100 \%$ & $100 \%$ & $100 \%$ & $100 \%$ & $100 \%$ \\
\hline & 8 & $\begin{array}{l}\text { Z Score for Haematology ( or Equivalent) } \\
\text { in EQAP-AIIMS, Delhi }\end{array}$ & 2.8 & 1.86 & 1.2 & 0.86 & $<2$ \\
\hline & 9 & Down time critical equipment & 5 days & 3days & 3 days & 36 hour & $<48$ hours \\
\hline & 10 & $\begin{array}{l}\% \text { Investigations out of Turn around time } \\
\text { for routine lab investigations }\end{array}$ & $9.1 \%$ & $6.1 \%$ & $5.8 \%$ & $6.0 \%$ & $5 \%$ \\
\hline & 11 & $\begin{array}{l}\% \text { Investigations out of Turn around time } \\
\text { (TAT) for emergency lab investigations }\end{array}$ & $5.8 \%$ & $3 \%$ & $3 \%$ & $2.2 \%$ & $5 \%$ \\
\hline \multirow{4}{*}{$\begin{array}{l}\text { Clinical } \\
\text { care and } \\
\text { safety }\end{array}$} & 12 & $\begin{array}{l}\% \text { of Critical values reported within one } \\
\text { hour }\end{array}$ & $95 \%$ & $95 \%$ & $97 \%$ & $96 \%$ & $100 \%$ \\
\hline & 13 & $\begin{array}{l}\text { Number of adverse events per thousand } \\
\text { patients }\end{array}$ & 2 & 1 & 0 & 1 & $<1$ \\
\hline & 14 & Report correlation rate & $92 \%$ & $95 \%$ & $97 \%$ & $97 \%$ & $100 \%$ \\
\hline & 15 & $\begin{array}{l}\text { Proportion of false positive/false negative } \\
\text { for Malaria pf/pv antigen test }\end{array}$ & 0.002 & 0.002 & 0.002 & 0.002 & $<0.005$ \\
\hline \multirow{2}{*}{$\begin{array}{l}\text { Service } \\
\text { Quality } \\
\text { Indicator }\end{array}$} & 16 & Waiting time at sample collection area & $15 \mathrm{~min}$ & $13 \mathrm{~min}$ & 10min & $10 \mathrm{~min}$ & $<15 \min$ \\
\hline & 17 & $\begin{array}{l}\text { Number of stock out incidences of } \\
\text { Reagents }\end{array}$ & 5 & 5 & 3 & 0 & 0 \\
\hline
\end{tabular}


to automatically communicate with the responsible provider has been demonstrated to reduce the critical value reporting time in controlled settings. For implementation of automated critical value reporting, interfaces from the LIS to technologies that facilitate bidirectional communication (such as e-mail or 2 - way pagers) need to be developed. By this way we will improve our critical value reporting time as close as $100 \%$. Up till now very limited studies over NQAS parameters so detail comparative study of other quality indicators not possible.

\section{Conclusion}

The concept of quality indicators has revolutionized the field of laboratory medicine. These indicators are of most importance in the comparison of individual laboratory performance with the aim of improving laboratory services and quality. It is now possible to compare our laboratory functions with others by simply evaluating the prevalence of the various indicators. It should be ensured that the quality of work is not compromised due to the quantity. We should strive to reach these benchmarks to provide the best services to society.

\section{Reference}

1. WHO (2008) Strengthening Public Health Laboratories in the WHO African Region: A Critical Need for Disease
Control. 58th Session of the WHO Regional Committee for Africa (AFR/RC58/R2), World Health Organization Regional Office for Africa, Yaounde.

2. Bonini P, Plebani M, Ceriotti F, Rubboli F. Errors in Laboratory Medicine. Clinical Chemistry 2002;48:691-698.

3. Agarwal R, Chaturvedi S, Chhillar N, Goyal R, Pant I, Tripathi CB. Role of Intervention on Laboratory Performance: Evaluation of Quality Indicators in a Tertiary Care Hospital. Indian Journal of Clinical Biochemistry 2012;27:61-68.

4. Ministry of Health and Family Welfare Government of India. Quality outcome indicators. Assessor's guide book for quality assurance in district hospital,1st ed. 2013;1:16.

5. Ministry of Health and Family Welfare Government of India. Quality outcome indicators. Assessor's guide book for quality assurance in district hospital,1st ed. 2013;2:108-225.

6. Steindel SJ, Novis DA. Using outlier events to monitor test turnaround time. A College of American Pathologist Q - Probe study in 496 laboratories. Arch Pathol Lab Med.1999;123: 607-14.

7. Bates DW, Pappius E, Kuperman GJ, Sittig D, Burstin H, Fairchild D et al. Using information systems to measure and improve quality. Int J Med Inform 1999;53:115-124.

8. Tate KE, Gardner RM, Weaver LK. A computerized laboratory alerting system. MD Comput 1990;7:296-301.

*Corresponding author:

Dr. Killol Nathubhai Desai, A-303, Tirth Apartment, Near Siddhanath Mahadev Temple, Zanzarada Road, Junagadh-362001 Gujarat, INDIA

Phone: +91 9428050253

Email: drkilloldesai@gmail.com

Financial or other Competing Interests: None. 